\title{
УЛААНБААТАР ХОТЫН ХӨРСНИЙ БОХИРДОЛ
}

\author{
о. Батхишиг. \\ ШУА-ын Газарзуйн хүрээлэн \\ email:batkhishig@gmail.com
}

\section{Soil pollution of Ulaanbaatar city}

According by soil investigation of Ulaanbaatar city area in 2012 soil heavy metal contamination generally was low. In some areas revealed anomaly high content of Chromium, Lead and Zink exceeding maximum allowed content. But this points a sporadic distributed not covered big area and 7.5-2.7 \% of samples are exceeding standard level. The soil ammonium and sulfate content is high comparing with non-polluted pasture soils. Soil ammonium pollution more closely connected with big open markets and "ger horoolol" area. Primary source of sulfate content is air pollution and coal burning. Soil microbiological pollution, E.Coli and anaerobic bacteria level is high. The "ger horoolol" district area becoming main source of microbiological pollution. Improvement of solid waste management and "ger horoolol" area planning is challenging issue to solve a soil pollution problem of Ulaanbaatar city area.

\section{Оршил}

Улаанбаатар хотын хүн амын төвлөрөл ихсэж, автомашины тоо, гэр хорооллын эзлэх талбай нэмэгдсэний улмаас хүрээлэн байгаа байгаль орчинд үзүүлэх сөрөг нөлөөлөл улам бүр ихсэж, хүн амын эрүүл мэнд, тав тухтай ажиллаж амьдрах орчин алдагдахад хүрч байна. Нийслэл хотод хүн амын тоо ихэссэнтэй холбоотой хатуу ба шингэн бохирдлын хэмжээ жил бүр ихсэж байна. Улаанбаатар хотод 2012 оны байдлаар 1236 786 хүн албан ёсоор бүртгэлтэй амьдарч байгаа нь Монгол улсын нийт (2012 онд $2869521)$ хүн амын 43,1 \% болж байгаа боловч хөдөө орон нутгаас 100 мянга гаруй оюутан сурагч суралцаж, мөн нилээд их хэмжээний хүмүүс ажил хэргээр хотод орж ирж байгааг тооцвол хүн амын бараг 50 \% орчим нийслэл хотод амьдардаг гэж хэлж болно. Хотын байгаль орчин түүний дотор хөрсөн бүрхэвчийн доройтол, бохирдол, элэгдэл эвдрэлийн өнөөгийн төлөв байдлын түвшинг тогтоож цаашид сайжруулах арга замыг тодорхойлох явдал тулгамдсан асуудлын нэг болж байна.

Хөрсөн бүрхэвчид хог хаягдал болон янз бүрийн бохирдуулагч элемент хуримтлагдаж байдаг учраас хөрсний бохирдолын судалгаа нь экосистемийн төлөв байдлыг тодорхойлогч гол үндсэн үзүүлэлт болдог. Иймээс бид Улаанбаатар хотын үндсэн дүүргүүдийн нутаг дэвсгэрт хөрс, экогеохимийн нөхцөлийг тодорхойлж, цаашид сайжруулах арга замыг тодорхойлох зорилгоор энэхүу судалгааг гүйцэтгэлээ[Батхишиг ба бусад, 2013]. Хөрсний бохирдлын судалгааг дэмжиж, туслалцаа үзүүлсэн БОНХЯ болон “Цэвэр Агаар” сангийн мэргэжилтнүүд болон бусад хүмүүст гүн талархал илэрхийлж байна.

1990-ээд оноос хойш хотын хөрсний бохирдолын судалгааны ажлууд хийгдэж эхэлсэн [Касимов бусад.,1995; Готовсүрэн 1995, Доржготов, Батхишиг 2004,]. 1995 онд А.Готовсүрэн, Г.А.Белоголовавнар Улаанбаатар хотод экологийн геохимийн судалгаа явуулж хэд хэдэн төрлийн техноген гажгуудыг тогтоосон байна. Эдгээр ажлууд нь Улаанбаатар хотын хүрээлэн байгаа байгаль орчны тэнцвэрт тогтолцоог хадгалах, хамгаалах, сайжруулах хүний үйл ажиллагааны нөлөөгөөр байгаль орчинд учирч буй сөрөг өөрчлөлтийг илрүүлэх, шинээр үүсч болзошгүй өөрчлөлтийг прогнозчлох, хот байгуулалтын хэтийн 
төлөвлөлтийг боловсруулахад ашиглагдаж иржээ. Сүүлийн жилүүдэд нийслэл хотын хөрсний бохирдлын шинэлэг ажлууд нилээд их хийгдэх болсон. Улаанбаатар хотын хөрсний металлын бохирдол, хөдөлгөөнт хэлбэрүүдийг Батжаргал, Отгонжаргал нар судалж хөрсний металлын бохирдол бага гэсэн дүгнэлт хийсэн байдаг [Batjargal et all, 2010].Мөн Оросын судлаачид хөрсний хүнд металл, хар тугалганы агууламж тархалтын талаар судалсан [Sorokino, 2012].

\section{Арга зүй}

2011-2012 онуудад Улаанбаатар хотын нутаг дэвсгэрээс нийт хөрсний 285 ш. дээж авч лабораторийн задлан шинжилгээ хийсэн. Хөрсний хими физик шинж чанарын ерөнхийүзүүлэлтүүдболоннитрат, аммоний, фосфор, сульфат зэрэг ҮзүүлэлтүҮдийг ШУА-ийн Газарзүйн хүрээлэнгийн Хөрс судлалын лабораторид, хөрсний бохирдлын элементүүд [Cd, $\mathrm{Pb}, \mathrm{As}, \mathrm{Hg}, \mathrm{Zn}, \mathrm{Ni}, \mathrm{Cu}$,

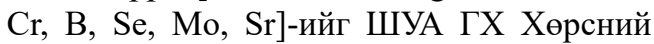
лабораторидатомын шингээлтийн [AACатомын адсорбцын] спектрофотометрийн аргаар, Ус сувгийг удирдах газрын Усны шинжилгээний Төв лабораторид ICP OES багажин дээртус тус тодорхойлсон. Хөрсний хүнд металлын агууламжийг тодорхойлоход түгээмэл ашиглагддаг хүчлийн задаргаa (aqua regia)ашигласан. Нийгмийн Эрүүл мэндийн хүрээлэнгийн лабораториднянгийн бохирдол буюу гэдэсний бүлгийн савханцар(E.Coli), анаэроб бактеримөөгөнцөр, эмгэг төрүүлэгч г.м. үзүүлэлтүүдийг тодорхойллоо.

Хөрсний бохирдолын түвшинг тогтооход харьцуулах стандарт буюу хүлцэх агууламж гэсэн үзүүлэлт үндсэн гол тулгуур үзүүлэлт болно. Мөн бохирдолд ороогүй бэлчээрийн хөрстэй харьцуулж судалсан. Монгол оронд мөрдөгдөж буй 2008 онд батлагдсан "Хөрс бохирдуулагч бодис, элементүүдийн зөвшөөрөгдөх дээд хэмжээ” [MNS 5850:2008] стандартыг ашигласан.

\section{Бохирдлын эх үүсвэр}

Нийслэл хотын хөрсөнд хаягдаж буй бохирдлыг хатуу ба шингэн гэж 2 хувааж болно. Хатуу хог хаягдалд ахуйн, барилгын, үйлдвэрийн, хөдөө аж ахуйн гаралтай хог хаягдал багтана. Нийт хатуу хог хаягдлын $70 \%$ орчмыг ахуйн хог хаягдал эзэлдэг гэсэн судалгааны дүн байдаг. Хотод өдөрт дунджаар 800- 1000 тн орчим хатуу хог хаягдал гардаг гэж үздэг. Эдгээр хог хаягдлын 20-30 \% орчим нь зориулалтын хогийн цэгд хаягдахгүй ил задгай хөрс, гуу жалганд хаягддаг байна.

Шингэн бохирдол нь бохир усны сувгаар дамжин цэвэрлэх байгуулжамжид очиж цэвэрлэгдэж байх ёстой. Нийслэл хотын хүн амын 60 \% нь буюу 185 мянган өрх гэр хороололд амьдарч нүхэн жорлон ашиглаж байна. Нүхэн жорлонгийн шингэн бохирдол нь газрын доорх ус болон хөрсийг бохирдуулагч томоохон бохирдлын эx үүсвэр болно. Мөн нийтийн бие засах газрууд нийслэл хотод хангалтгүй байдгаас шалтгаалж иргэд хашааны булан, задгай газар бие засаж хөрсийг бохируулдаг.

\section{Судалгааны үр дүн}

Хөрсний бохирдлын гол үзүүлэлтүүдийн нэг болох хүнд металлууд нь гадаад орчинд тэсвэртэй бөгөөд хөрсөнд удаан хугацаанд хадгалагдаж улмаар ногоон ургамалд шимэгдэх замаар мал, амьтан, мөн хүний хүнс тэжээлийг бохирдуулдаг.

Бохирдолд ороогүй бэлчээрийн хөрстэй харьцуулахад нийт судалгаанд хамрагдсан хөрсний дээжний 26,7-77,2 $\%$ нь хүнд металлын агууламж өндөр байна. Харин Монгол улсад мөрдөгдөж буй хөрсний бохирдолын стандарт [MNS 58:50]-тай харьцуулахад нийт дээжний 2,77,5 \% стандартаас их бохирдолтой байна.

2012 оны байдлаар УБ хотын хөрсний Хромын дундаж агууламж 56.4 ppm байгаа нь бохирдоогүй газрын хөрснөөс 2 дахин их байна. Зарим газруудад 1512 - 1548.8ppm хүрч байна. Арьс ширны үйлдвэрүүд, урьдчилан цэвэрлэх байгууламж орчим хромын бохирдолт 607-555 pрm хүртэл байгаа нь бохирдоогүй хөрнөөс 20 дахин, стандарт хэмжээнээс 3-4 дахин их байна.

Хөрсний Хар тугалганы дундаж 
агууламж 33.3 ppm байгаа нь бохирдоогүй газрын хөрснөөс 2 дахин их байна. Нүүрсний тортог, автомашины шатахуунаас гарч байгаа хар тугалга агаарын тоосонцорт илүҮ ихээр агуулагдаж байна. Хөрсөнд никелийн дундаж агууламж стандартаас бага буюу 9.9ppm,хамгийн ихдээ 52.0 ppm хүрчээ. Никелийн агууламж тоосонд харьцангуй өндөр буюу 76.1ppm байна. Цайрын агууламж хөрсөнд дунджаар 194.9ppm, тоосонд харьцангуй их буюу 253.9pрm байна.

Хүнцэлийн дундаж агууламж 13.5 мг/кг байгаа бөгөөд Улиастай, Дамбадаржаа зэрэг газруудын гэр хороололд дунджаар 6.1-63.9 мг/кг буюу стандартаас их байна. Янз бүрийн судалгааны дүнгээр Монгол орны төвийн бүсийн бэлчээрийн хөрсөндХүнцэлийн агууламж 2-20 мг/кг хүртэл байдаг бөгөөд энэ нь хурдас чулуулгаас хамааралтай юм. Улаанбаатар хотын хөрсний Хүнцэлийн агууламж Монгол орны бэлчээрийн хөрсөнд байдаг агууламжтай адил хэмжээнд буюу бохирдолд ороогүй гэж үзэж болно.

Хотын хөрсний хүнд металлын бохирдолтыг нийтэд нь дүгнэх нийлбэр бохирдолтын итгэлцүүр [Zc] гэсэн үзүүлэлтийг хэрэглэдэг. Энэ нь хүнд металлын агууламжийг бохирдоогүй хөрсний үзүүлэлтэд харьцуулсан энгийн үзүүлэлт юм. Хотын хойд хэсэг, зүүн хэсэг, арьсширний үйлдвэр орчим хөрсний хүнд металлын нийлбэр бохирдолт өндөр байна.

Нянгийн бохирдолт нь харьцангуй тогтворгүй үзүүлэлт болох бөгөөд дулааны улиралд илүү идэвхжиж, хүйтний улиралд багасдаг. Бид нянгийн бохирдолтын дээжлэлтийг дулааны улиралд авсан. Нийт авсан хөрсний дээжний $72 \%$ нь нянгийн бохирдолтой байна. Үүний 45.8\% бага зэргийн, 20.8\% дунд зэргийн, 4\% их хэмжээний нянгийн бохирдолтой байгаа нь судалгаагаар тогтоогдлоо. Дээрхи төрлийн бактериуд гэр хорооллын хогийн цэг, нүхэн жорлонтой ойрхон, хог хаягдал ихтэй газрын хөрсөнд илэрсэн байна. Хөрсөн дэх E.Coli бактерийн бохирдолт $60 \%$ нь бага, $32 \%$ нь дунд зэрэг, 8\% нь их хэмжээгээр бохирджээ. Анаэробын бичил биетэн Cl.prefrings нийт дээжний $82 \%$ илэрч $19 \%$ дунд зэргийн, $81 \%$ бага бохирдолтойбайна.Хөгц мөөгөнцөр мөн л хог хаягдал ихтэй газруудын хөрсөнд илэрч байгаа нь цаашид Улаанбаатар хотын хөрсөн дэх нянгийн хэмжээг бууруулах ажлыг хотын гэр хороолол дунд үүссэн хог хаягдлыг цэвэрлэх, нүхэн жорлонгийн нөхцлийг сайжруулах зэргээс эхлэх шаардлагатай байгааг харуулж байна.

\section{УБ хотын хөрсний хүнд металлын дундажс УзУҮлэлтүҮд, ррт}

ХУснэгт 1.

\begin{tabular}{|c|c|c|c|c|c|c|}
\hline ҮзүҮлэлт & $\mathrm{Pb}$ & $\mathrm{Cr}$ & $\mathrm{Ni}$ & $\mathrm{Zn}$ & $\mathrm{Cd}$ & $\mathrm{Co}$ \\
\hline Дундаж[2012он] & 33.3 & 56.4 & 9.9 & 177.5 & 0.57 & 1.7 \\
\hline Хамгийн их & 1512.5 & 1548.8 & 52.0 & 662.3 & 7.2 & 24.2 \\
\hline Хамгийн бага & 0.5 & 1.3 & 0.0 & 0.0 & 0.0 & 0.1 \\
\hline Стандартаас их, \% & 2.7 & 5.9 & 0.0 & 7.5 & 3.0 & 5.3 \\
\hline $\begin{array}{l}\text { Бохирдоогүй } \\
\text { хөрснөөс их, \% }\end{array}$ & 75,5 & 69,2 & 77,2 & 71,9 & 39,7 & 26,7 \\
\hline $\begin{array}{l}\text { Дэвсгэр агууламж } \\
\text { [Гачуурт, Алтанбулаг] }\end{array}$ & 15 & 25 & 8 & 130 & 0.3 & 8 \\
\hline $\begin{array}{l}\text { Стандарт } \\
\text { [MNS } 5850: 2008]\end{array}$ & 100 & 150 & 150 & 300 & 3 & 50 \\
\hline
\end{tabular}


Улаанбаатар хотын хөрсний нийт дээжний аммонийн дундаж агууламж 8.3 мг/ кг байгаа нь бохирдолгүй хөрсний дэвсгэр агууламжаас 5.5 дахин өндөр байна. Нийт бохирдлын судалгааны дээжний $66.7 \%$ нь дэвсгэр агууламжаас давсан аммонийн агууламжтай, 33.3\% нь дэвсгэр агууламжтай ойролцоо буюу түүнээс бага хэмжээний аммони агуулсан байна.

Шивтрийн бохирдлын хэмжээгээр худалдаа үйлчилгээний төвүүдийн ойролцоох газрууд эхэнд орж байгаа бол дараа нь гэр хорооллын гудамжууд, автобусны буудлууд орно. Улаанбаатар хотод хөрсний шивтрийн бохирдол харилцан адилгүй байна. Хүн амын төвлөрөл ихтэй худалдаа үйлчилгээний томоохон төвүүдийн ойролцоо аммонийн агууламж хамгийн их байгаа юм. Тухайлбал: Нарантуул худалдааны төвийг тойрсон гэр хорооллын гудамжуудад хамгийн их буюу 1кг хөрсөнд 73.4 мг аммонийн азот байгаа нь дэвсгэр агууламжаас 50 дахин их, дэнжийн мянгын захын ойролцоо 64.6 мг/кг байгаа нь дэвсгэр агууламжаас 43 дахин их байна. Дүүргээр авч үзвэл Баянзүрх, Чингэлтэй дүүргүҮд хамгийн их бохирдолтойбайна.

\section{Дүгнэлт}

УБ хотод хөрсний нянгийн бохирдолтын түвшин өндөр, хүнд металлын бохирдолтын ерөнхий түвшин бага байгаa боловч зарим газруудад хэт их бохирдолтууд ажиглагдаж байна. Арьс ширний үйлдвэр, Ногоон нуур, 100 айл, томоохон захууд, гэр хороолол гэх мэт газруудад бохирдолт илүү их байна. УБ хотын хөрсөнд нянгийн бохирдол их, халдварт өвчин үүсэх эрсдэл өндөр байна. Нянгийн бохирдол үүсэх гол шалтгаан нь гэр хорооллын нүхэн жорлон, ил задгай бие засах болон ахуйн хог хаягдал болно.

Хөрсний бохирдлыг бууруулах талаар төр захиргааны байгууллага, нийт ард иргэд анхаарах шаардлагатай байна. Хог хаягдлын менежментийг сайжруулах, хог боловсруулах үйлдвэрүүдийг төрөлжүүлэн байгуулах, хогийг ангилж хаях, дахин боловсруулах,цэвэр хоггүй байр, хороо, гудамжийг шагнаж урамшуулах.г.м. Хөрсний бохирдол онцгой их байгаа Хар хорин, Да хүрээ, 100 айл, Нарантуул зэрэг томоохон худалааны төв, зах орчмын газрын тохижолтын асуудалд онцгой анхаарах шаардлагатай. Ил задгай авто засвар, дугуй засварын газруудыг тохижуулах, эрүүл ахуйн шаардлага хангаагүй газруудыг хаах нь зүйтэй. Хог хаягдлын хуулийг амьдралд хэрэгжүүлэх шаардлагатай байна.

\section{Ашигласан бүтээлийн жагсаалт}

1. Batjargal T, Otgonjargal E, Baek K, Yang JS. Assessment of metals contamination of soils in Ulaanbaatar, Mongolia. J Hazard Mater. 2010 Dec 15;184(1-3):872-6.

2. БатхишигО, Доржготов Д, Нямсамбуу Н, ба бусад. Улаанбаатар хотын хөрснийбохирдол, эко-геохимийн үнэлгээ” Судалгааны тайлан. БОНХЯам, Цэвэр агаар сан. УБ 2013.,

3. Готовсүрэн А, Белоголовав Г.А, Эрдэнэдэлгэр Д, Янжмаа Ж, “Улаанбаатар хотын экологийн геохимийн судалгааны тайлан” ЭХГУУЯ Геохимийн судалгааны товчоо. УБ 1995 он 141 хууд.

4. Касимов Н.С, Лычагин М.Ю, Евдокимова А.К и др. Улан-Батор, Монголия [теплоэнергетика]. Межгорная котловина в кн. “Экогеохимия городских ландшафтов” под ред. проф. Н.С.Касимова: Изд-во МГУ.1995 с. 231-249

5. “Улаанбаатар хотын экогеохимийн судалгаа, үнэлгээ”., Нийслэлийн хот байгуулалтын хүрээлэн.МУИС, ГХ ШУА., 1999

6. “Чингэлтэй дүүргийн хөрсний, бохирдлын судалгаа”Чингэлтэй дүүргийн Иргэдийн Төлөөлөгчдийн Хурал. УБ 2003

7. Доржготов Д, Батхишиг О, Батсайхан Г. Улаанбаатар хотын хөрсний бохирдол Нийслэлийн 365 жилийн ойд зориулсан эрдэм шинжилгээний бага хурал. 2004. УБ

8. "Улаанбаатар хотын ундны усны төвийн эх үүсвэр орчмын газрын бохирдолын судалгаа". 
Судалгааны тайлан зураг зөвлөмж. Нийслэлийн Хот Байгуулалт хөрөнгө Оруулалтын Газар. УБ 2004.

9. “Улаанбаатар хотын хөрсөн бүрхэвч, хөрсний эвдрэл, бохирдолын тойм”.,Нэгдсэн үндэстний байгууллагынбайгаль орчны хөтөлбөр" [UNEP]. УБ 2007.

10. Монгол улсын стандарт“Хөрс бохирдуулагч бодис, элементүүдийн зөвшөөрөгдөх дээд хэмжээ” [MNS 5850:2008]

11. Sorokina O. I, Enkh-AmgalanS.Lead in the landscapes of Ulaanbaatar city (Mongolia). Arid Ecosystems January 2012, Volume 2, Issue 1, pp 61-67 